\title{
Digital Activism: a Hierarchy of Political Commitment
}

\author{
Jordana George \\ Baylor University \\ jordana_george@baylor.edu
}

\author{
Dorothy E. Leidner \\ Baylor University and University of Lund \\ dorothy_leidner@baylor.edu
}

\begin{abstract}
Political action has a long history. Information systems provide new affordances for political action that go well beyond sending an email to elected officials or "liking" a political Facebook page. Digital activism -- political action enabled by Information Systems (IS) -- not only provides citizens with enhanced opportunities for organization and communication, but also allows opportunities to take direct political action and create greater impact with fewer resources. This paper seeks to explore and build theory on the use and impact of digital activism by extending Milbrath's hierarchy of political participation to reflect digital activism. The paper contributes to both the IS and political science literature with a digital activism framework that builds on digital activism theory.
\end{abstract}

\subsection{Introduction}

News headlines blaze ever more frequently with tales of companies taken offline by political hacktivists or some politician's secret leaked to the public. Social media has turned into a battleground where long-time comrades "unfriend" each other over political disagreements [46], where enormous rallies and demonstrations are organized [27], [3], and where civic hackathons, a venue for altruistic citizens to code for their country, abound [12], [22]. Digital activism has allowed political bodies to span boundaries and gain new adherents in record time. For better or worse, information systems (IS) are now an established part of the political landscape [50]. This paper seeks to explore and build theory on the use and impact of digital activism.

Digital activism refers to the use of digital technologies by an individual, group, or organization to enact political change. It offers efficient organizational coordination, boundary expansion, and rapid news dispersion [3], [27], [35], [43], thus potentially and rapidly expanding the number of people involved. IS expands the means for activism in new ways and with new capabilities [43]. It also incites a new breed of political activist by lowering the entry barrier for participation [42]. Digital activism also encompasses e-participation, the use of digital tools to provide government services [25]. We compare digital activism with traditional activism, which embodies mainstream activities such as voting, attending rallies, or writing letters to officials. Unlike the more limited scope of traditional activism, digital activism provides a means to take direct action. Direct action occurs when an individual takes action himself that might include releasing confidential information via leaks, participating in a denial of service attack to punish an opposing party, or contributing to a civic hackathon. The implications of taking direct action are an under-researched area and one where this work hopes to make a contribution with a framework of digital activism. Our contribution matters to IS research because if we can understand how, when, and why digital activism develops, we may be able to effect change. We may be able to reduce negative activities such as "black hat" hacking or redirect it into positive ones. We may be able to find ways to increase beneficial involvement across society in general.

Our paper is organized as follows: we first provide an overview of political action research based on a hierarchy of political participation. We then review the research on digital activism. Based on both literature streams, we provide a framework of digital activism. We then conceptualize how the forms of digital activism vary and use this as a springboard to draw insights for future research.

\subsection{Background}

Researchers have studied political action in depth since the 1950s. Early research focused on why citizens did or did not vote while later studies examined broader political actions such as funding candidates and campaign participation [32]. 
Political action is defined as "action taken...to gain control of the political state" [7]. People take political action to effect change in government.

Political action scholarship covers a wide range of theories. Some come from an economic viewpoint, such as Downs (1957) or Stigler (1971) while other theories focus on social aspects of political action, such as Bourdieu (1989). Milbrath's hierarchy of political participation focuses on individual action [31]. We selected Milbrath's model because of its simplicity and applicability in its original form to the IS phenomenon of digital activism. Milbrath was the first to explain political participation in terms of increasing activities and to suggest that those at higher levels still engage in lower level undertakings and that political activity is cumulative [4]. Starting with apathy (no political participation), Milbrath's hierarchy maps out thirteen political activities into three increasing levels of participation: spectator activities (the lowest level of commitment and effort), transitional activities (medium level), and gladiatorial activities (highest level). The hierarchy is illustrated in Figure 1. Spectator activities include wearing political buttons or placing campaign signs in one's yard. Transitional activities require more effort. For example, attending a political rally would be considered transitional. Milbrath's framework culminates in gladiatorial activities that require significant resources, such funding a cause or organizing a political party. Thus Milbrath describes the entire political action journey from exposing oneself to a political idea to ultimately holding public office.

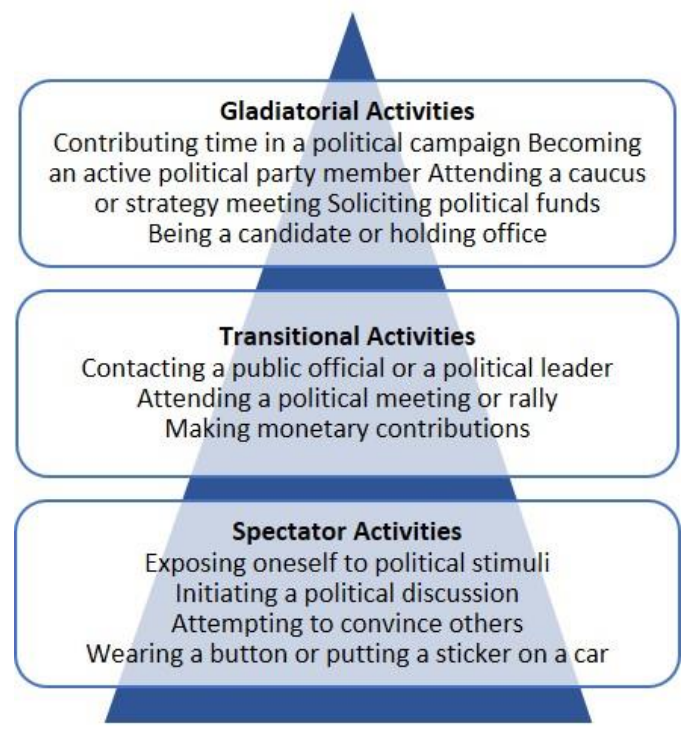

Figure 1. Hierarchy of political participation (from Milbrath 1965)
Milbrath's hierarchy describes traditional political action. Traditional political action includes voting, belonging to a political party, wearing a party button, adorning a vehicle with bumper stickers, and contributing funds. In the $19^{\text {th }}$ and $20^{\text {th }}$ centuries, physical protest and marches (traditional political action) were the primary methods of political action. Instances include the European and American women's suffrage movements, the civil rights movement, and the anti-Vietnam demonstrations. Advances in technology then paved the way for new forms of political action collectively referred to as digital activism.

\subsection{Digital Activism}

Digital activism is the appropriation of information systems (IS) to enact political action. Table 1 compares traditional and digital activism.

Table 1. Differences between traditional and digital activism

\begin{tabular}{|c|c|c|}
\hline Aspect of Activism & Traditional & Digital \\
\hline Requires access to technology & & $\mathrm{X}$ \\
\hline News of events spreads fast & & $\mathrm{X}$ \\
\hline Reaches broad audience & & $\mathrm{X}$ \\
\hline Member retention issues & $\mathrm{X}$ & $\mathrm{X}$ \\
\hline Appeals to younger constituents & & $\mathrm{X}$ \\
\hline Appeals to older constituents & $\mathrm{X}$ & \\
\hline Easy recruiting & & $\mathrm{X}$ \\
\hline Video and photos easily spread & & $\mathrm{X}$ \\
\hline Events may be organized quickly & & $\mathrm{X}$ \\
\hline Ease of raising money & & $\mathrm{X}$ \\
\hline Constant reinforcement & & $\mathrm{X}$ \\
\hline Requires a lot of resources & $\mathrm{X}$ & \\
\hline Individual and minority voices are heard & & $\mathrm{X}$ \\
\hline Provides transparency & $\mathrm{X}$ & $\mathrm{X}$ \\
\hline Uncurated messages are common & & $\mathrm{X}$ \\
\hline Takes time to build a coalition & $\mathrm{X}$ & \\
\hline Range of effort by participants & $\mathrm{X}$ & $\mathrm{X}$ \\
\hline
\end{tabular}

In both types of activism, political organizations must motivate people to not only participate but to continue participation. People may drop out because participants may not believe their contribution makes a difference or they may prioritize other activities above political action. When activity evolves from the physical to the virtual, such limitations as time and place become less relevant. Some scholars and the popular press bemoan what appears to be the disinterest of younger generations in citizenship and traditional political action [2], but others suggest the landscape is simply changing from duty-based concepts of citizenship, such as voting, to a more engaged form based on tolerance and social justice [21]. Young people appear to be more engaged on 
digital platforms compared to traditional forums, as well. A 2014 Ipsos MORI survey demonstrated that $88 \%$ of $18-29$ year old Britons believed social media provides a voice to people who have been historically left out of the political conversation [53].

Scholars are noting the varied means of and results from digital activism. For example, Selander and Jarvenpaa employ the term digital action repertoires to describe the various options available to enact digital activism, and which are legitimized through the values of the organization [73], [74]. We also find that the internet is a major aid to political messaging and inclusiveness and provides even poorly funded causes the ability to communicate to a broad audience. This was seen in movements such as $15 \mathrm{M}$ in Spain, a protest conducted by "Los Indignados" (the indignant ones) in 60 cities in May of 2011, or the 2011 Al-Huwaider online campaign for women's rights in in the Middle East [3].

The IS artifacts used for political action include a range of technologies, from cell phones to personal computers to sophisticated servers, tools, and applications. Cell phones have had great influence because of low cost and ready supply. The ability to quickly communicate with people has enabled rapid organization of protests and demonstrations through text messaging. This phenomenon has been documented in Spain during 15M [30], in Africa where cell phone coverage is directly correlated with violent political action [36], and in the Middle East during Arab Spring [3]. A 2016 Pew survey noted that half of social media users were frustrated with political posts [14] while an earlier 2012 Pew survey found that $66 \%$ of social media users have shared political views [37]. Social media are easy to join and use, and easy for organizations to leverage with APIs that integrate websites with social media [24]. Such integration speeds the dissemination of political messages and propaganda and reinforces ideology.

Social media also makes it easier for people to gain meta-knowledge, or the "who knows what" and "who knows who" that surrounds an issue [26]. All of this builds political socialization. Rimmerman defines political socialization as "the process by which citizens acquire their attitudes and beliefs about the political system in which they live and their roles within that system" [38]. Social media provides new outlets for very low effort action. The new terms "slacktivism" and "clicktivism" indicate political action expressed through "liking" a candidate or political post or sharing it on social media, and it is characterized by having little real world effect [45], [49]. This is somewhat contradictory, as one would expect greater participation to result in greater impact, but slacktivism by definition demonstrates the opposite. However, even low-level action on social media may lead to greater involvement such as volunteering and is intensified if others in a social network are also involved [49].

Political social media is an effective organizational method for movements around the globe and may spread information that governments wish to hide [48]. Political social media can be used for recruitment, as well, which is exemplified by Jihad Jane's use of YouTube videos and social media to recruit jihadist fighters online [10]. Moreover, political social media can incite people to action, build global support, and challenge repression [27], [1].

Publishing on social media may also bring danger and even death for posters in countries with strict laws governing public expressions of dissent. Political social media may be used to protest in less open countries where traditional political actions such as demonstrations are banned. An example is the Twitter account of Loujain Al Hathloul, a woman who drove from the UAE to the Saudi Arabian border and was promptly arrested for driving (because she was female), as was her friend who arrived to help her [6]. The Twitter accounts of both women chronicled their journey until the feed promptly stopped when they were taken to prison. Using Twitter for women's rights in Saudi Arabia continues today with hashtags such as \#Women2Drive and \#saudiwomen [47]. In less open countries, social media can and does effect change, as is seen in the example of the Al-Huwaider online campaign that promoted women's rights and improved their position [1].

After political social media, the other major phenomenon in digital activism is hacking. Political hackers generally fall into three categories: hacktivists, civic hackers, and patriotic hackers. The term "hacking" may refer to individuals acting out personal missions, but a good deal of hacking today is politically motivated and therefore falls into the realm of digital activism [9]. Unlike most other forms of political action, traditional or non-traditional, hacking takes direct action on perceived political players.

Political hackers typically act on a "set of political interventions orchestrated by geeks and hackers" [9]. The technical methods required by hackers demand education and skills. In their professional life, hackers may be employed as security analysts, programmers, or system administrators. Hackers and 
geeks often hold deep-seated respect for openness and freedom of information and may act to achieve or maintain these principles [9]. Political action hacking differs from political social media in the level of skills required. Anyone with a social media account and a device may participate in Twitter or Facebook. Hacking, on the other hand, mandates specific skills [9].

Hacktivism is political action enacted through hacking and other direct IS actions [23]. It includes spreading viruses and malware that enable political messages, attacking and disseminating confidential information, and performing denial of service (DOS) attacks, among other activities. Hackers, in general, wreak havoc for a variety of reasons, but hacktivists support specific political agendas and their actions are designed to force change, create alternatives to existing government venues, or punish those who act against their values [40]. Some hacktivist organizations remain concealed while some publicize their exploits to drive home their message. Anonymous, one of the most well-known groups, falls into this latter category. Anonymous is known for distributed denial of service attacks (DDOS) and has demonstrated a technical evolution that has grown in sophistication over the years [40]. Anonymous developed tools designed for DDOS that include automation that allows the group to strike organizations and cause great damage with few participants. Anonymous does not launch a DDOS just for the sake of hacking, however. It launches a DDOS to punish organizations that act against its values [40].

The "white hats" or "good guys" in the world of political hacking are the civic hackers, as they term themselves [41]. They call themselves "hackers" because they act outside of traditional government processes and may use unorthodox and innovative means to solve problems. Civic hackers belong to loosely organized groups that perform IS actions such as building and updating government digital systems or working towards data activism [21]. Civic hackers may work alone, join a distributed group, or participate in local hackathons that are focused on specific tasks to help the government or community [22]. Civic actions might include redesigning a government website, developing a new system to solve a particular problem or helping to connect open government data. Civic hackathons are an interesting new phenomenon that builds citizenship and a sense of belonging to the community [21], [12]. One of the largest events is the US National Day of Civic Hacking, started in 2016 and celebrated in over 70 cities across the US [51].
The third type of political hacker is the patriotic hacker. Working alone or in groups, the patriotic hacker focuses his or her efforts towards enemy countries and their citizens [18]. These hackers are not state-sponsored, although state-sponsored hacking certainly exists [39]. Patriotic hackers may see themselves as able to act where the state cannot. They are nationalistic and see themselves as a citizen "cyber-militia" [19]. Unlike other hacker types, the patriotic hacker does not limit action to organizations. They will attack individuals in enemy countries as well as governments and companies.

Returning to Milbrath's hierarchy as a lens to view digital activism, eight types of digital activism are distinguished and listed below in order of the level of individual political commitment. They include clicktivism, register a view, fund a cause, vote with your wallet, guaranteed response, data preservation, information exposure, and hacktivism. Some of these actions are digitized forms of traditional actions, such as online fundraising, and others are unique to digital activism, such as hacking. The eight actions are explained in detail below. Table 2 summarizes the actions with Hierarchical Level (Spectator, Transitional, or Gladiatorial), Type (one of the eight activities examined), Effort Level, and Potential Impact on a cause or organization.

Table 2. Digital activism hierarchy

\begin{tabular}{|l|l|l|l|}
\hline $\begin{array}{l}\text { Hierarchy } \\
\text { Level }\end{array}$ & Type & $\begin{array}{l}\text { Potential impact on a cause or } \\
\text { organization }\end{array}$ & Effort \\
\hline $\begin{array}{l}\text { Spectator } \\
\text { Activities }\end{array}$ & Clicktivism & $\begin{array}{l}\text { Affects those in your social media } \\
\text { network on an individual level, } \\
\text { does not force action }\end{array}$ & Low \\
\cline { 2 - 5 } & $\begin{array}{l}\text { Register a } \\
\text { view }\end{array}$ & $\begin{array}{l}\text { Potential impact ranges from very } \\
\text { low to medium, depending on } \\
\text { volume, does not force action }\end{array}$ & Low \\
\hline Transitional & $\begin{array}{l}\text { Fund a } \\
\text { cause }\end{array}$ & $\begin{array}{l}\text { Potential impact ranges from very } \\
\text { low to low, does not force action }\end{array}$ & Medium \\
\cline { 2 - 5 } & $\begin{array}{l}\text { Political } \\
\text { consumer- } \\
\text { ism }\end{array}$ & $\begin{array}{l}\text { Potential impact ranges from very } \\
\text { low to medium-low, affects sellers } \\
\text { and providers, impact ranges } \\
\text { depending on volume, does not } \\
\text { force action }\end{array}$ & Medium \\
\cline { 2 - 5 } & $\begin{array}{l}\text { Guaran- } \\
\text { reed }\end{array}$ & $\begin{array}{l}\text { Medium, affects administration } \\
\text { but only guarantees a response, } \\
\text { not what the response will be, } \\
\text { forces action }\end{array}$ & Medium \\
\hline
\end{tabular}




\begin{tabular}{|l|l|l|l|}
\hline $\begin{array}{l}\text { Gladiatorial } \\
\text { Activities }\end{array}$ & $\begin{array}{l}\text { Data } \\
\text { activism }\end{array}$ & $\begin{array}{l}\text { Medium-high, affects citizens, } \\
\text { data journalists, governments, } \\
\text { researchers and academics in } \\
\text { health care, STEM, and } \\
\text { business, action taken by } \\
\text { individuals }\end{array}$ & High \\
\cline { 2 - 5 } & $\begin{array}{l}\text { Informa- } \\
\text { tion } \\
\text { exposure }\end{array}$ & $\begin{array}{l}\text { High, affects governments, } \\
\text { citizens, industry, on individual } \\
\text { and organizational level, action } \\
\text { taken by individuals, may have } \\
\text { severe impact on the actor if } \\
\text { done openly }\end{array}$ & High \\
\cline { 2 - 5 } & $\begin{array}{l}\text { High, affects governments, } \\
\text { citizens, industry, on individual } \\
\text { and organizational level, action } \\
\text { taken by individuals }\end{array}$ & High \\
vism & \multicolumn{2}{|c|}{} & \\
\hline
\end{tabular}

\subsection{Spectator Activities}

3.1.1 Clicktivism. Clicktivism or slacktivism allows an individual to share political views with his/her social network. It is usually triggered upon viewing social media and is enacted by "Liking" or sharing on social media. Anyone can use this technology and with a mobile device, can perform it anywhere. It is considered a low form of engagement because it is noncommittal and impersonal [28]. Clicktivism requires little effort and the potential impact on an organization or policy is also low [45]. Most importantly, it does not force action or take direct action.

3.1.2 Register a view. This action describes sharing an opinion with an organization, government agency or politician. It is triggered when the individual wants his/her voice heard on an issue and is enacted via web form, email, online petition, web survey, and eparticipation. Anyone can perform these actions and it can be performed anywhere with an internet connection. The effort is relatively low, but does require more effort than hitting a "Like" button. The potential impact on an organization or policy from these actions ranges from very low to medium. In their study of Amnesty International (AI), Selander and Jarvenpaa found that online petitions broadened the reach of the organization, but new participants did not necessarily share the values of AI and many in AI questioned the power of 50,000 digital signatures government organization, but a relatively low volume may have little or no effect. Registering a view does not force action.

\subsection{Transitional Activities}

3.2.1 Fund a cause. In traditional political activism one can write a check to fund a cause, but in terms of digital activism, we define funding a cause as using technology, such as online donations, to give money to a political cause or candidate. Funding actions are triggered by an election, event, or policy and are enacted via e-commerce. Nearly anyone can perform this action because it requires only the financial means (having the money and an e-commerce payment option - PayPal, credit card, etc.) and a device. It may be performed anywhere and the effort is fairly low. Funding a cause is also impersonal because an online donation does not require deep commitment [43]. The potential impact on an organization or cause ranges from very low to low for most IS enabled donations, because very large donations are generally managed on an individual basis outside of the organization's website.

3.2.2 Political consumerism. Political consumerism supports one's political views through purchasing habits and allows a citizen to financially support a business that agrees with his or her political views while avoiding support of firms that promote dissenting views [34]. It is triggered when a citizen wants to make a financial gift to demonstrate his or her political commitment. Political consumerism can be enacted via social media and websites, as well as mobile applications, such as $2^{\text {nd }}$ Vote [8]. Anyone who makes purchases and uses a smartphone can use this technology to determine if a seller meets his/her personal political criteria. The action is performed at a place of business or via e-commerce transaction. The effort for the individual is medium and requires remembering to use the app. The potential impact on an organization ranges from very low to medium-low and affects sellers and providers. The impact ranges depending on volume. It does not force action.

3.2.3 Guaranteed response. The guaranteed response is a relatively new phenomenon created by the US Whitehouse in 2011 [15]. It forces administration response to a particular issue if the request garners enough support from other citizens. It is triggered by an event or policy or a desire for a new policy. Enacted via the Whitehouse website, the Whitehouse Petition allows citizens to submit a petition [52]. If the petition gathers 100,000 signatures within 30 days, the administration must respond to the petition. Anyone can access the system and it can be performed anywhere. The effort is medium because the originator must gather enough signatures, as is the impact because it only guarantees a response. It does not dictate what the response will be. The guaranteed response forces action. 


\subsection{Gladiatorial Activities}

3.3.1 Data activism. In data activism, volunteers rescue, preserve, and promote open data to protect open government [41]. It is triggered when closed governments refuse to share data or when open government is threatened by the removal of open data. It is enacted by building repositories, sharing data, copying open datasets via scripts, screen scrapes, bots, or manually copying data. It often involves data cleaning and data wrangling into machine readable format and uploading to an open data repository [5]. Participation is generally limited to those with data science skills. It may be performed anywhere, and may also be performed at civic hackathons. The effort is high and the activities often require specialized querying and semantic web tools, such as SPARQL, JSON, or R. The potential impact is medium-high, and affects citizens, governments, researchers, and academics in health care, business, and STEM (science/technology/engineering/math).

3.3.2 Information exposure. Information exposure is the dissemination of confidential information, or a leak [17]. It is enacted via WikiLeaks, the press, or social media. Actors are limited to those with access to confidential information. Information gathering is performed within the organization that owns the information and sharing that information may be done anywhere. The effort is high because the actor must have access and must be able to get the information out. Once information is in possession of the actor, sharing it is easy (SNS, the press, WikiLeaks). The potential impact is high, and it affects governments, citizens, and industry, on individual and organizational levels. The action is taken by individuals (who may be directed by political or government organizations) and may have severe consequences for the actor, so it may be considered a dangerous action [48]. Information exposure is direct action taken by individuals.

3.3.3 Hacktivism. Hacktivists target organizations or politicians. Hacking is triggered by an event or policy or when one party appears to be gaining over another. It is enacted through computer code that exposes information or disrupts operations. Limited to those with coding and programming skills, hacktivism often incorporates security breaching [9]. Hacktivism may be performed anywhere but it often requires extra security measures for concealment. The effort is very high because the actor must ferret out access. The potential impact is high, and it affects governments, citizens, industry, on individual and organizational level. It is direct action taken by individuals and hacker organizations. In Figure 2, digital activism is explained in terms of the resources required compared to the impact gained. The figure demonstrates a continuum of low to high resources and low to high potential impact. Those activities in the upper right quadrant (high resources and high impact) tend to be those that force action.

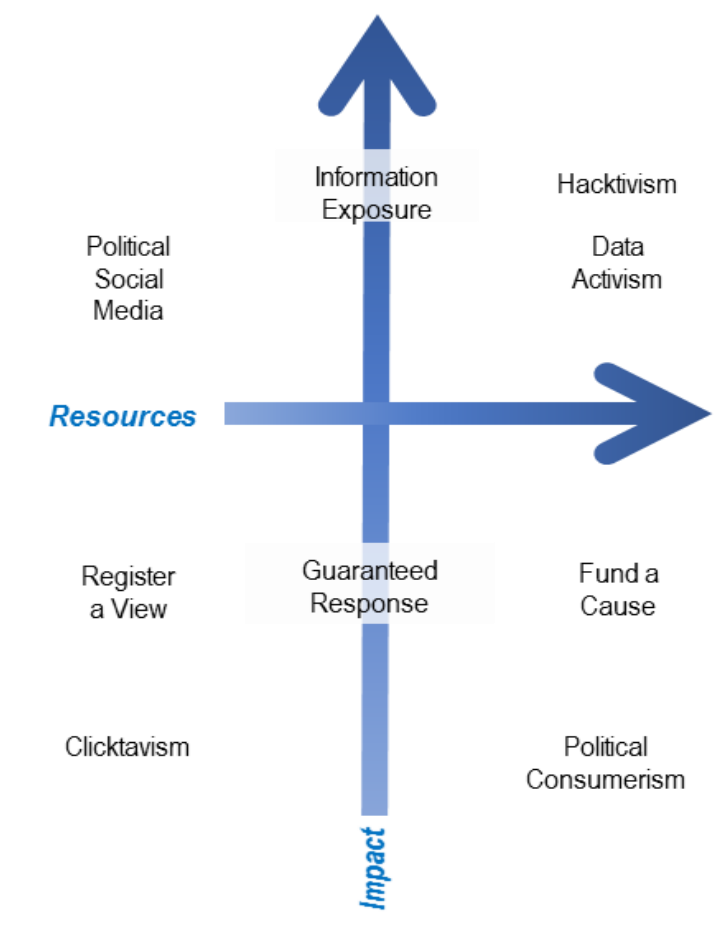

Figure 2. Resources vs. impact

One important way that these forms of digital activism vary is that of the impact potential of a single individual. In traditional political action, single individuals were unlikely to be able to generate a response from a government or organization without first organizing a substantial body of supporters. Some forms of digital activism are similar; in particular, the spectator and transitional activities are unlikely to generate official response unless substantial numbers of individuals are involved. However, the gladiatorial activities give even one individual extensive power.

\subsection{Opportunities for Research}

There are a number of research opportunities within digital activism on several levels of analysis. At the individual level, there are three combined aspects that influence action when they interact: (1) actor IS skill level; (2) actor political commitment; and (3) the effort required by a specific political action. Actor IS skill level is a measure of the 
technical skills that an actor possesses, such as programming, coding, security, graphics, video editing, or other knowledge and experience. Some digital activism requires few skills, such as social media sharing, "liking," and following. Content creation for political social media, such as videos or data charts, requires a higher skill level. Hacking, DDOS, and security breaches require the highest skill levels.

Political commitment varies considerably between people, causes, and organizations [48]. Political commitment is the subjective amount of resources (including personal effort) an individual is willing to expend to support his or her cause. It may be measured in terms of time, inconvenience such as travel, or financial support. These measures are relative and subjective [48]. A donation of $\$ 100$ is large for poor citizens but a pittance for wealthy individuals. Therefore, financial support should be measured relative to the individual's wealth. A day of volunteering mid-week might be a huge commitment for someone who must take off work, but it may be a small commitment for a college student on break. Tufekci suggests that supporting gay marriage on social media is a "thin" or minor effort for a college student on a liberal campus, but a "thick" or considerable commitment for a small-town teenager from a conservative family [48]. Further development of the actor political commitment construct would benefit our understanding of digital activism.

Political actions vary in the effort they require to enact. Political action effort may be measured in terms of resources, time, access, number of people, or other quantifiable measures. Clicking a Follow button on social media may be assumed to be a low effort action because it requires only one person and one second of time, and occurs in a venue where the person is likely already engaging with social media posts. The opposite end of this spectrum might consist of a civic hackathon, where thousands of people must be organized across communities around the country and where the events require significant volunteer hours to produce the desired result. The effort required by specific digital activism activities, particularly compared to their impact, is another aspect that would benefit from additional research.

\subsection{Implications and Conclusion}

The affordances of digital activism include broad and fast communications and the ability to take direct action that goes beyond protests, voting, or sharing opinions with members of the government. There are several aspects to widespread, quick communications. First, individuals may be apprised almost immediately of political news. This means that there is little time for government organizations to "spin" news, a term that describes how government agencies position and describe events to better reflect upon themselves. The speed of news dispersion biases the trajectory of political news, allowing some news to become viral, regardless of its actual importance or veracity. For example, recently President Trump tweeted a mistyped word, "covfefe," and the Twitterverse exploded with questions and comments about the word's meaning [44]. In past years, a typographical error would have been ignored by news sources and the public. Research is needed to understand whether and how such immediacy of information affects political engagement.

Second, political news used to be curated by the press or by a government organization's press secretary. Today, news and information may be spread directly by officials on their personal Twitter accounts, via individuals capturing events live on their cellphone, or through leaked documents shared in a digital format. This means that information today is not filtered the same way it was in the past. It comes to readers in raw form, requiring citizens to process the information themselves. The breadth of information exposes citizens to a wide expanse of viewpoints. On the other hand, the sheer volume of information available can be overwhelming to citizens, leading them to focus their information consumption to a few key sources. Such focus may lead to a narrowed worldview. Thus, digital activism can paradoxically widen viewpoints through greater exposure to new ideas but limit and harden viewpoints through ideologically focused news sources. Future research should explore the mechanisms that produce enhanced worldviews versus those that work to reinforce or harden existing views.

Third, citizen reporting provides a new level of transparency. Viral videos graphically illustrate government actions and the speed of video dispersion can quickly create riots and protests. This implies that governments should take such transparency into consideration when planning action. In closed governments, agencies may need to impose draconian measures to halt information sharing. In contrast, officials in open governments must be able to quickly deal with any aftermath from highly charged events that are publicized and politicized through digital means. An example is the internet-fueled Black Lives Matter movement that encourages filming of police shootings and posting video online as events occur 
[16]. Such videos increase transparency and draw attention to abuses of power, but may also lack context and give false impressions. Both authorities and citizens need to be able to rationally use citizen reporting and understand its limitations at the same time. Future research is needed to examine how digital activism enables transparency and in what ways activists might need to keep their own activities opaque in order to create transparency around an issue.

Fourth, digital activism can influence with little effort or resources. This means that less visible and poorly funded groups are now able to publicize and promote their views. One example is the LGBT (Lesbian/Gay/Bi/Trans) community in China that uses internet venues for support and organization. Future research should examine how such less visible and poorly funded groups are able to create visibility for their causes. And in the presence of many varied potential causes, research is needed to understand how individuals decide which causes to notice.

In regards to digital activism's opportunities for direct action by individuals, the implications are grave. Hacktivists don't wait for politicians to act for them, they wage action directly to initiate change. Hacktivists may target government agencies, private firms, or individuals. For example, if hackers decided to expose the medical records of all US senators in order to force change in healthcare policy, they could do so. It is also conceivable that hackers could initiate an automatic tax refund, hijack satellite coverage, or hold US stock exchanges hostage. Albeit challenging, research into the mindset of political hackers is needed to understand what drives such individuals to potentially put the well-being of many people at risk for the sake of furthering a political agenda.

In conclusion, as digital technologies spread and more people use them, we can expect to see greater incidents of digital activism. If specific events tend to stimulate action and if individuals with the political commitment and requisite skills to use an IS are incited to action, an IS political action is not only likely to be enacted, but we may be able to surmise how and when it may occur. Such foreknowledge may assist organizations and governments in contingency planning and defensive strategies to avoid or minimize operational disruption and security leaks, and may aid citizen groups in maximizing the potential of their action.

The level of digital activism we see today is likely a precursor to major actions undertaken by the citizens of the future [50]. As technology develops along with citizen IS skills, the opportunity to take direct action through organization, coordination, disruption, information theft, and virtual vandalism increases. It is important to realize that digital activism is not easily categorized as "good" or "bad." Researchers and practitioners have the opportunity to enable positive actions and mitigate the risk of adverse actions.

\subsection{References}

[1] Agarwal, N., Lim, M., and Wigand, R. Raising and Rising Voices in Social Media: A Novel Methodological Approach in Studying CyberCollective Movements. Business \& Information Systems Engineering 4, 3 (2012), 113-126.

[2] Alex-Assensoh, Y.M. Democracy at Risk: How Political Choices Undermine Citizen Participation and what We Can Do about it. Brookings Institution Press, 2005.

[3] Anduiza, E., Cristancho, C., and Sabucedo, J.M. Mobilization through online social networks: the political protest of the indignados in Spain.

Information, Communication \& Society 17, 6 (2014), 750-764.

[4] Axford, B., Browning, G.K., Huggins, R., Rosamond, B., Turner, C.R.S.J., and Turner, J. Politics: An Introduction. Routledge, 2005.

[5] Baack, S. Datafication and empowerment: How the open data movement re-articulates notions of democracy, participation, and journalism. Big Data \& Society 2, 2 (2015).

[6] Bager, J. Saudi Women Right-to-Drive Activists Deploy Twitter, Face Terrorism Court. Time, 2015. http://time.com/3697073/saudi-arabia-women-drivetwitter/.

[7] Batt, D.E. and Dannenberg, K. The BattDannenberg Debate on Resolved, that by Political Action Alone, Without the Assistance of the Socialist Industrial Union, the Workers Can Emancipate Themselves ... Between Dennis E. Batt, Representing the Socialist Party, and Karl Dannenberg, Representing the Workers' International Industrial Union. Literature Bureau of the Workers' International Industrial Union, 1919.

[8] Becker, A.B. and Copeland, L. Networked publics: How connective social media use facilitates political consumerism among LGBT Americans. Journal of Information Technology \& Politics 13, 1 (2016), 22-36. 
[9] Coleman, G. Hacker Politics and Publics. Public Culture 23, 365 (2011), 511-516.

[10] Dale, M. 'Jihad Jane': Pennsylvania woman charged with recruiting jihadists online. Associated Press, 2010. http://www.cleveland.com/nation/index.ssf/2010/03/p ennsylvania_woman_charged_wit.html.

[11] Dalton, R.J. The Good Citizen: How a Younger Generation Is Reshaping American Politics. SAGE, 2008.

[12] DiSalvo, C., Gregg, M., and Lodato, T. Building belonging. Interactions 21, 4 (2014), 58-61.

[13] DuBois, E.C. Feminism and Suffrage: The Emergence of an Independent Women's Movement in America, 1848-1869. Cornell University Press, Ithaca and London, 1999.

[14] Duggan, M., and A. Smith, The Political Environment on Social Media, 2016.

[15] Elmer, G., Langlois, G., and Redden, J. Compromised Data: From Social Media to Big Data. Bloomsbury Publishing USA, 2015.

[16] Garza, A. A HerStory of the \#BlackLivesMatter Movement. BlackLivesMatter, 2014. http://blacklivesmatter.com/herstory/.

[17] Gellman, B. and Markon, J. Edward Snowden says motive behind leaks was to expose 'surveillance state.' Washington Post, 2013.

[18] Goel, S. Cyberwarfare: connecting the dots in cyber intelligence. Communications of the ACM 54, 8 (2011), 132.

[19] Green, K. People's War in Cyberspace: Using China's Civilian Economy in the Information Domain. Military Cyber Affairs 2, 1 (2016).

[20] Hallin, D.C. The Uncensored War: The Media and Vietnam. University of California Press, 1989.

[21] Hunsinger, J. and Schrock, A. The democratization of hacking and making. Sage Publications, 2016.

[22] Johnson, P. and Robinson, P. Civic Hackathons: Innovation, Procurement, or Civic Engagement? Review of Policy Research 31, 4 (2014), 349-357.

[23] Jordan, T. and Taylor, P.A. Hacktivism and Cyberwars: Rebels with a Cause? Psychology Press, London; New York, 2004.

[24] Kane, G.C., Alavi, M., Labianca, G. (Joe), and Borgatti, S.P. What's Different About Social Media Networks? A Framework and Research Agenda. MIS
Quarterly 38, 1 (2014), 275-304.

[25] Lee, J., and S. Kim, “Active Citizen EParticipation in Local Governance: Do Individual Social Capital and E-Participation Management Matter?", 2014 47th Hawaii International Conference on System Sciences, (2014), 2044-2053.

[26] Leonardi, P.M. Social Media, Knowledge Sharing, and Innovation: Toward a Theory of Communication Visibility. Information Systems Research 25, 4 (2014), 796-816.

[27] Lynch, M. After Egypt: The Limits and Promise of Online Challenges to the Authoritarian Arab State. Perspectives on Politics 9, 02 (2011), 301-310.

[28] Majchrzak, A., Faraj, S., Kane, G.C., and Azad, B. The Contradictory Influence of Social Media Affordances on Online Communal Knowledge Sharing. Journal of Computer-Mediated Communication 19, 1 (2013), 38-55.

[29] Megyery, K. Women in Canadian Politics: Volume 6: Toward Equity in Representation. Dundurn, Toronto and London, 1991.

[30] Micó, J.-L. and Casero-Ripollés, A. Political activism online: organization and media relations in the case of $15 \mathrm{M}$ in Spain. Information, Communication \& Society 17, 7 (2014), 858-871.

[31] Milbrath, L. Political Participation: How and Why Do People Get Involved in Politics? Rand McNally, 1965.

[32] Milbrath, L.W. Political Participation. In S.L. Long, ed., The Handbook of Political Behavior. Springer US, 1981, 197-240.

[33] Morris, A.D. The Origins of the Civil Rights Movement. Simon and Schuster, New York, 1986.

[34] Newman, B.J. and Bartels, B.L. Politics at the Checkout Line: Explaining Political Consumerism in the United States. Political Research Quarterly 64, 4 (2011), 803-817.

[35] Oh, O., Agrawal, M., and Rao, H.R. Community intelligence and social media services: A rumor theoretic analysis of tweets during social crises. Mis Quarterly 37, 2 (2013), 407-426.

[36] Pierskalla, J.H. and Hollenbach, F.M. Technology and Collective Action: The Effect of Cell Phone Coverage on Political Violence in Africa. American Political Science Review 107, 02 (2013), 207-224.

[37] Rainie, L., Smith, A., Schlozman, K.L., Brady, H., and Verba, S. Social media and political 
engagement. Pew Internet \& American Life Project 19, (2012).

[38] Rimmerman, C.A. The New Citizenship: Unconventional Politics, Activism, and Service. Westview Press, 2010.

[39] Rosenberg, S.S., Matthew and Lehren, A.W. WikiLeaks Releases Trove of Alleged C.I.A. Hacking Documents. The New York Times, 2017.

[40] Sauter, M. "LOIC Will Tear Us Apart": The Impact of Tool Design and Media Portrayals in the Success of Activist DDOS Attacks. American Behavioral Scientist 57, 7 (2013), 983-1007.

[41] Schrock, A.R. Civic hacking as data activism and advocacy: A history from publicity to open government data. New Media \& Society 18, 4 (2016), 581-599.

[42] Selander, L. and Jarvenpaa, S. Innovating with Digital Action Repertoires at Amnesty International: Exploring Role Ambiguity. 2016 49th Hawaii International Conference on System Sciences (HICSS), (4614-4623.

[43] Selander, L. and Jarvenpaa, S. Digital Action Repertories and Transforming a Social Movement Organization. Management Information Systems Quarterly 40, 2 (2016), 331-352.

[44] Shaban, H. The COVFEFE Act would preserve Trump's tweets as presidential records. Washington Post, 2017.

[45] Shirky, C. The political power of social media: Technology, the public sphere, and political change. Foreign affairs, (2011), 28-41.

[46] Sibona, C. and Walczak, S. Unfriending on Facebook: Friend Request and Online/Offline Behavior Analysis. 2011 44th Hawaii International Conference on System Sciences, (2011), 1-10.

[47] Taylor, A. A social media campaign to get Saudi women driving finds support but also mockery. Washington Post, 2016.

[48] Tufekci, Z. The Medium and the Movement: Digital Tools, Social Movement Politics, and the End of the Free Rider Problem: The End of the Free Rider Problem. Policy \& Internet 6, 2 (2014), 202-208.

[49] Vitak, J., Zube, P., Smock, A., Carr, C.T., Ellison, N., and Lampe, C. It's Complicated:

Facebook Users' Political Participation in the 2008 Election. Cyberpsychology, Behavior, and Social Networking 14, 3 (2011), 107-114.

[50] Wattal, S., Schuff, D., Mandviwalla, M., and
Williams, C.B. Web 2.0 and Politics: The 2008 U.S. Presidential Election and an E-Politics Research Agenda. MIS Quarterly 34, 4 (2010), 669-688.

[51] Code for America. Code for America, 2017. https://www.codeforamerica.org/.

[52] Petitions. whitehouse.gov. petitions.whitehouse.gov, 2017.

[53] A third of young people think social media will influence their vote, Ipsos MORI, 2015. 